\title{
Influence of Alkali Treatment on the Surface Area of Aluminium Dross
}

\author{
N. S. Ahmad Zauzi, ${ }^{1}$ M. Z. H. Zakaria, ${ }^{1}$ R. Baini, ${ }^{1}$ M. R. Rahman, ${ }^{1}$ \\ N. Mohamed Sutan, ${ }^{2}$ and S. Hamdan ${ }^{3}$ \\ ${ }^{1}$ Department of Chemical Engineering and Sustainability Energy, Faculty of Engineering, Universiti Malaysia Sarawak, \\ 94300 Kota Samarahan, Sarawak, Malaysia \\ ${ }^{2}$ Department of Civil Engineering, Faculty of Engineering, Universiti Malaysia Sarawak, 94300 Kota Samarahan, \\ Sarawak, Malaysia \\ ${ }^{3}$ Department of Mechanical Engineering and Manufacturing, Faculty of Engineering, Universiti Malaysia Sarawak, \\ 94300 Kota Samarahan, Sarawak, Malaysia
}

Correspondence should be addressed to N. S. Ahmad Zauzi; aznsyuhada@unimas.my

Received 18 March 2016; Accepted 25 May 2016

Academic Editor: Guocheng Lv

Copyright ( 2016 N. S. Ahmad Zauzi et al. This is an open access article distributed under the Creative Commons Attribution License, which permits unrestricted use, distribution, and reproduction in any medium, provided the original work is properly cited.

\begin{abstract}
Aluminium dross is an industrial waste from aluminium refining industry and classified as toxic substances. However, the disposal of dross as a waste is a burden to aluminium manufacturer industries due to its negative effects to the ecosystem, surface, and ground water. Therefore the purpose of this study is to evaluate the influence of sodium hydroxide $(\mathrm{NaOH})$ on the surface area and pore size of aluminium dross. There were 3 stages in the treatment activities, which were leaching, precipitation, and calcination process. The optimum result from this study was the surface area of aluminium dross increases from $10.1 \mathrm{~m}^{2} / \mathrm{g}$ up to $80.0 \mathrm{~m}^{2} / \mathrm{g}$ at $40^{\circ} \mathrm{C}, 1 \% \mathrm{NaOH}$, and 15 -minute reaction time. Thus, aluminium dross has a potential to be converted into other useful material such as catalyst and absorbent. The benefit of this research is that the hazardous industrial waste can be turned into wealth to be used in other applications such as in catalytic activities and absorber in waste water treatment. Further investigation on the physicochemical of aluminium dross with different acid or alkali should be conducted to get deeper understanding on the aluminium dross as a catalyst-type material.
\end{abstract}

\section{Introduction}

Aluminium dross is one type of the industrial wastes which are generated in a recycle of an aluminium recycle process. There are three types of aluminium dross which are black dross, white dross, and salt cake. White dross is generated in aluminium smelting industries while black dross and salt cake are generated in the aluminium recycling industries. Amount and the formation of these substances depend on several factors such as the type and quality of input materials, operating conditions, the type of technology, and furnace applied. The overall chemistry depends on the alloying elements present in the molten aluminium and the metallurgical process [1]. Generally, this dross may contain $\mathrm{Al}_{2} \mathrm{O}_{3}, \mathrm{AlN}, \mathrm{Al}_{4} \mathrm{C}_{3}, \mathrm{SiO}_{2}, \mathrm{MgO}, \mathrm{Al}$, and minor quantities of
Si [2]. According to Sultana et al. [3], it was estimated that $15-25 \mathrm{~kg}$ of dross is produced per metric tonne of molten aluminium and [4] stated that, throughout the world, it was estimated that 5 million tonnes of an aluminium dross was generated every year.

Aluminium dross is classified as a toxic industrial waste and it requires a proper treatment before it can be discharged. Majority of aluminium dross is disposed in open landfill sites, and this activity can cause harm to the environment due to the toxic ions; there is possibility of toxin ions leached out from the disposed aluminium dross into the ground water, which can cause pollution [4-6]. This substance is usually treated as a landfilled solid waste [6]. The disposal cost of this waste can be expensive; RM 2000.00 per tonne will be charged by the approved local disposal waste company for the disposal in 
TABLE 1: Chemical composition of raw aluminium dross.

\begin{tabular}{lllllllll}
\hline Composition & $\mathrm{SiO}_{2}$ & $\mathrm{Al}_{2} \mathrm{O}_{3}$ & $\mathrm{Fe}_{2} \mathrm{O}_{3}$ & $\mathrm{MgO}$ & $\mathrm{SO}_{3}$ & $\mathrm{CaO}$ & $\mathrm{TiO}_{2}$ & $\mathrm{Na}_{2} \mathrm{O}$ \\
\hline 1.2 & 89.8 & 0.54 & 0.84 & 0.15 & 0.41 & 0.022 & 0.31 \\
\hline
\end{tabular}

\begin{tabular}{lllllllll}
\hline wt\% & 1.2 & 89.8 & 0.54 & 0.84 & 0.15 & 0.41 & 0.022 & 0.31
\end{tabular}

Malaysia [7]. A large amount of aluminium dross has never been treated properly prior to discharge due to the high cost of treatment and transportation.

Although aluminium dross is a type of waste, several useful usages have been discovered, such as filler in composite, being used in refractories industry, and also being used as adsorbent. Aluminium dross can be leached with copper chloride water solution to obtain aluminium oxychloride, $\mathrm{Al}(\mathrm{OH}) \mathrm{Cl}_{2}$, and then can be further treated with aluminium hydroxide to obtain aluminium chloride, $\mathrm{Al}_{2}(\mathrm{OH})_{5} \mathrm{Cl}$, which can be used as a coagulant in water treatment process [8]. Other than that, aluminium dross can be used as a deoxidizer to remove oxygen in the steel-manufacturing process and used as aggregate in cement processing [4].

More studies on treatment process for aluminium dross are necessary to increase the possibility of recycling this dangerous waste into useful products. Therefore, the aim of this work is to study the possibility of producing commercial catalyst from aluminium dross. In this work, aluminium dross has been treated using different concentration of sodium hydroxide for different temperatures and reaction time.

\section{Experimental}

Aluminium dross in this study was obtained from aluminium smelting industry, Press Metal Company, which is located in Samalaju Industrial Park, Bintulu, Sarawak. Three processing stages were applied to aluminium dross: leaching with sodium hydroxide, precipitation with hydrogen peroxide, and calcination. The first process was carried out by adding $10 \mathrm{~g}$ of aluminium dross with size $<300 \mu \mathrm{m}$ to a $250 \mathrm{~mL}$ of sodium hydroxide $(\mathrm{NaOH})$ with concentrations of $1 \%$, $5 \%, 10 \%$, and $20 \%$, stirring time of 15 minutes, 30 minutes, 45 minutes, and 60 minutes, and temperatures of $25^{\circ} \mathrm{C}$, $40^{\circ} \mathrm{C}, 55^{\circ} \mathrm{C}$, and $70^{\circ} \mathrm{C}$. The next process was the precipitation with hydrogen peroxide by adding $250 \mathrm{~mL}$ of $30 \%$ hydrogen peroxide $\left(\mathrm{H}_{2} \mathrm{O}_{2}\right)$ to samples. The mixtures were stirred for 30 minutes at room temperature, filtered, and washed with distilled water. In the final stage, the samples were calcined at temperature of $600^{\circ} \mathrm{C}$ for 3 hours

The chemical composition of raw and treated aluminium dross was analysed using X-Ray Fluorescence Spectroscopy (XRF) equipment (Bruker S4 EXPLORER X-Ray Fluorescence). The surface area and pore size of aluminium dross were determined using BET surface analysis (Quantachrome Instruments Co. Ltd.).

\section{Results and Discussion}

The chemical composition of aluminium dross (wt\%) obtained from XRF is given in Table 1. It was found that almost $90 \%$ of the raw material consists of $\mathrm{Al}_{2} \mathrm{O}_{3}$ and the
TABLE 2: Effect of time on the surface area of aluminium dross at temperature of $25^{\circ} \mathrm{C}$ and concentration of $\mathrm{NaOH}$ at $1 \%$.

\begin{tabular}{lllll}
\hline Time (mins) & 15 & 30 & 45 & 60 \\
\hline Surface area $\left(\mathrm{m}^{2} / \mathrm{g}\right)$ & 79 & 49 & 28 & 28 \\
\hline
\end{tabular}

TABLE 3: Effect of temperature on the surface area of aluminium dross at reaction time of 15 minutes and concentration of $\mathrm{NaOH}$ at $1 \%$.

\begin{tabular}{lllll}
\hline Temperature $\left({ }^{\circ} \mathrm{C}\right)$ & 25 & 40 & 55 & 70 \\
\hline Surface area $\left(\mathrm{m}^{2} / \mathrm{g}\right)$ & 79 & 80 & 51 & 47 \\
\hline
\end{tabular}

TABLE 4: Effect of $\mathrm{NaOH}$ concentration on the surface area of aluminium dross at reaction time of 15 minutes and temperature at $25^{\circ} \mathrm{C}$.

\begin{tabular}{lcccc}
\hline $\mathrm{NaOH}(\%)$ & 1 & 5 & 10 & 20 \\
\hline Surface area $\left(\mathrm{m}^{2} / \mathrm{g}\right)$ & 79 & 38 & 74 & 21 \\
\hline
\end{tabular}

remaining $10 \%$ consists of $\mathrm{SiO}_{2}, \mathrm{Fe}_{2} \mathrm{O}_{3}, \mathrm{MgO}, \mathrm{SO}_{3}, \mathrm{CaO}$, $\mathrm{TiO}_{2}$, and $\mathrm{Na}_{2} \mathrm{O}$.

In the first stage of treatment, hydrogen gas was formed during the leaching process with sodium hydroxide. The details of reactions in the first and second stages are given by (1)-(3) and (4), respectively:

$$
\begin{gathered}
\mathrm{Al}+3 \mathrm{H}_{2} \mathrm{O}+\mathrm{NaOH} \longrightarrow \mathrm{NaAl}(\mathrm{OH})_{4}+\frac{3}{2} \mathrm{H}_{2} \\
\mathrm{NaAl}(\mathrm{OH})_{4} \longrightarrow \mathrm{Al}(\mathrm{OH})_{3}+\frac{3}{2} \mathrm{H}_{2}
\end{gathered}
$$

The overall reaction can be summarized as follows:

$$
\begin{gathered}
\mathrm{Al}+3 \mathrm{H}_{2} \mathrm{O} \longrightarrow \mathrm{Al}(\mathrm{OH})_{3}+\frac{3}{2} \mathrm{H}_{2} \\
\mathrm{NaAlO}_{2}+2 \mathrm{H}_{2} \mathrm{O}_{2} \longrightarrow \mathrm{Al}(\mathrm{OH})_{3}+\mathrm{NaOH}+\mathrm{O}_{2}
\end{gathered}
$$

3.1. BET Surface Area. The surface area of the raw aluminium dross analysed using BET surface analysis was found to be $10.061 \mathrm{~m}^{2} / \mathrm{g}$, while the surface area for treated samples is given in Tables 2-4. Table 2 represents the effect of time on the surface area of aluminium dross with temperature of $25^{\circ} \mathrm{C}$ and concentration of $\mathrm{NaOH}$ at $1 \%$. Table 3 represents the effect of temperature on the surface area of aluminium dross with time at 15 minutes and temperature at $25^{\circ} \mathrm{C}$ concentration of $\mathrm{NaOH}$ at $1 \%$. Table 4 represents the effect of $\mathrm{NaOH}$ concentration on the surface area of aluminium dross with time of 15 minutes at $25^{\circ} \mathrm{C}$. Based on Tables 2-4, it was found that all the treated samples have larger surface area up to $700 \%$, compared to untreated one. This occurrence can be explained due to the process of dealumination and it will cause the disintegration surface of aluminium dross [9]. Besides, the increases of BET surface area with the presence of alkali are due to the production of finely dispersed silicon oxides from destruction of mineral structures and removal 


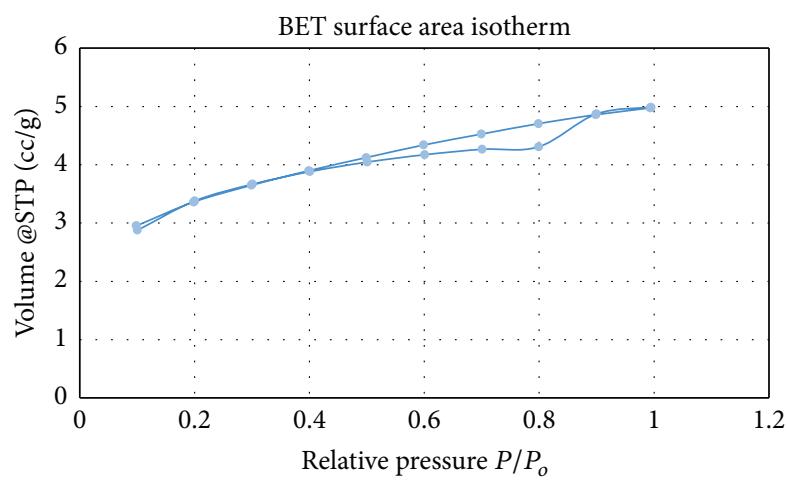

FIGURE 1: Isotherms of raw aluminium dross.

of amorphous of $\mathrm{Al}$ or silica components and thus increase the surface pores [10]. A large value of BET surface area will reflect the catalytic activity of the material.

On the effect of time, it shows that the surface area of aluminium dross increases when aluminium dross stirred for 15 minutes but as the time increases until 60 minutes, it may be seen that the surface area of aluminium dross decreases. The catalytic activity may reach a maximum at 15 minutes of reaction time whereas the effectiveness of catalysts could be reducing as the time increases [11].

This experiment was carried out with different temperatures which are $25^{\circ} \mathrm{C}, 40^{\circ} \mathrm{C}, 55^{\circ} \mathrm{C}$, and $70^{\circ} \mathrm{C}$, respectively. In Table 3 , at $25^{\circ} \mathrm{C}$, it shows the surface area of aluminium dross increases from $10 \mathrm{~m}^{2} / \mathrm{g}$ to $79 \mathrm{~m}^{2} / \mathrm{g}$. But as the temperature increases up to $70^{\circ} \mathrm{C}$, the pattern of the surface area decreases. At higher temperature, aluminium dross was found to be agglomerated; thus the surface of aluminium dross may be ruptured due to high temperature $[11,12]$.

Table 4 shows the effect of concentration of sodium hydroxide on the surface area of aluminium dross. In this experiment, the concentrations of sodium hydroxide used are $1 \%, 5 \%, 10 \%$, and $20 \%$, respectively. With the concentration of $1 \%$ of sodium hydroxide, the surface area of aluminium dross increases from $10 \mathrm{~m}^{2} / \mathrm{g}$ to $79 \mathrm{~m}^{2} / \mathrm{g}$. From the table, the surface area of aluminium dross decreases as the concentration of sodium hydroxide increases. Other than that, the maximum concentration for leaching process is at $1 \%$ whereas the surface area of aluminium dross decreases when the concentration increases due to saturation of aluminium dross at higher $\mathrm{NaOH}$ concentration [11].

Figures 1, 2, 3, and 4 are the nitrogen adsorption and desorption isotherms for raw aluminium dross and treated with $1 \%$ concentration of sodium hydroxide, stirring time of 30 minutes, and leaching temperatures of $25^{\circ} \mathrm{C}, 40^{\circ} \mathrm{C}$, and $55^{\circ} \mathrm{C}$, respectively. Figures show that the amount of $\mathrm{N}_{2}$ absorbed increases with the relative pressure. The slope of the curve decreases as the relative pressure decreases, which may indicate that the amount of $\mathrm{N}_{2}$ absorbed is reaching the equilibrium state. According to International Union of Pure and Applied Chemistry (IUPAC), those isotherms can be classified as type I which indicates adsorption and desorption on a microporous solid with pore size below $2 \mathrm{~nm}$. This type of isotherms showed high uptakes of nitrogen gas at

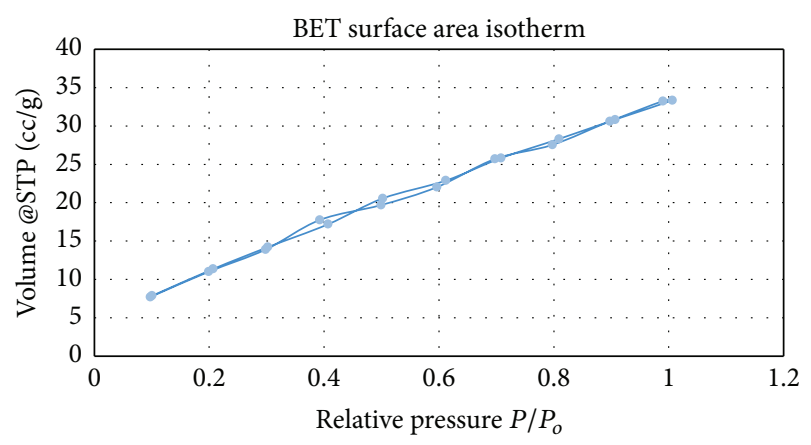

FIgURE 2: Isotherms of aluminium dross treated with $1 \%$ of $\mathrm{NaOH}$ at 30 minutes and temperature of $25^{\circ} \mathrm{C}$.

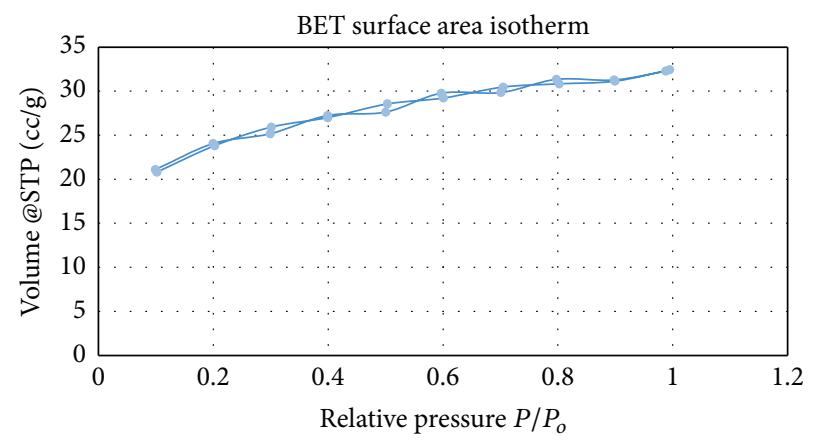

FIGURE 3: Isotherms of aluminium dross treated with $1 \%$ of $\mathrm{NaOH}$ at 30 minutes and temperature of $40^{\circ} \mathrm{C}$.

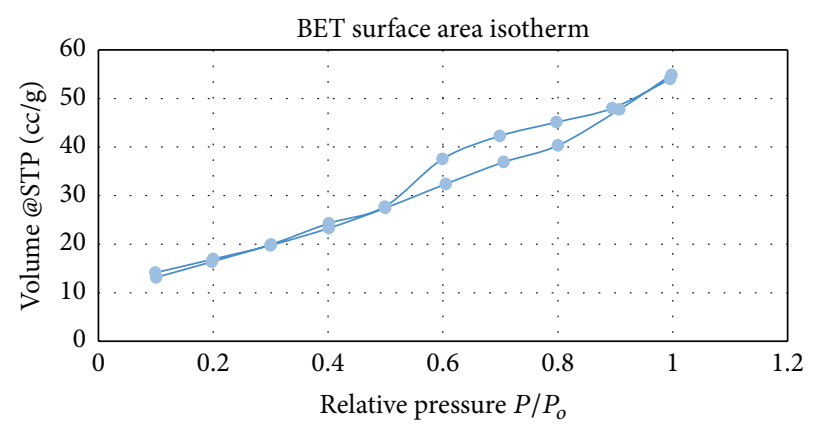

FIGURE 4: Isotherms of aluminium dross treated with $1 \%$ of $\mathrm{NaOH}$ at 30 minutes and temperature of $55^{\circ} \mathrm{C}$.

relatively low pressure due to the narrow pore width and high adsorption potential.

\section{Conclusion}

The characteristics of aluminium dross after being treated with different concentrations of $\mathrm{NaOH}$, at different reaction time and temperatures, were studied. It shows that, at 15 minutes, the surface area of aluminium dross increases but as the time increases, the surface area decreases. It also shows that at $1 \%$ concentration of $\mathrm{NaOH}$, the surface area of aluminium dross increases but it seems to decrease as the concentration of $\mathrm{NaOH}$ increases. Surface area of aluminium 
dross also reaches a maximum catalytic activity when the temperature is at $25^{\circ} \mathrm{C}$ but when the temperature increases, it shows decreasing of the surface area of aluminium dross due to the rupture of pores. $\mathrm{N}_{2}$ adsorption-desorption shows that aluminium dross was type I which is microporous solids. Therefore based on the BET surface analysis, aluminium dross has a potential to be a catalyst-type material and reduce the waste of aluminium dross. For further study, it is recommended to focus on other physicochemical properties of treated aluminium dross.

\section{Competing Interests}

The authors declare that the grant, scholarship, and/or funding mentioned in Acknowledgments do not lead to any conflict of interests. Additionally, the authors declare that there is no conflict of interests regarding the publication of this paper.

\section{Acknowledgments}

The authors are thankful to the Ministry of Higher Education for funding under FRGS/1/2015/SG06/UNIMAS/03/1 and Universiti Malaysia Sarawak.

\section{References}

[1] H. N. Yoshimura, A. P. Abreu, A. L. Molisani, A. C. De Camargo, J. C. S. Portela, and N. E. Narita, "Evaluation of aluminum dross waste as raw material for refractories," Ceramics International, vol. 34, no. 3, pp. 581-591, 2008.

[2] J. C. E. Bocardo and J. T. Torres, "Development of mullite/zirconia composites from a mixture of aluminum dross and zircon," Ceramics International, vol. 35, no. 2, pp. 921-924, 2009.

[3] U. K. Sultana, F. Gulshan, M. A. Gafur, and A. S. W. Kurny, "Kinetics of recovery of alumina from aluminium casting waste through fusion with sodium hydroxide," American Journal of Materials Engineering and Technology, vol. 1, no. 3, pp. 30-34, 2013.

[4] N. Murayama, I. Maekawa, H. Ushiro, T. Miyoshi, J. Shibata, and M. Valix, "Synthesis of various layered double hydroxides using aluminum dross generated in aluminum recycling process," International Journal of Mineral Processing, vol. 110-111, pp. 4652, 2012.

[5] B. R. Das, B. Dash, B. C. Tripathy, I. N. Bhattacharya, and S. C. Das, "Production of $\eta$-alumina from waste aluminium dross," Minerals Engineering, vol. 20, no. 3, pp. 252-258, 2007.

[6] S.-J. Yoo, D.-H. Kwak, S.-I. Lee et al., "Kinetics of aluminum dross dissolution in sec-butyl alcohol for aluminum secbutoxide," Advanced Powder Technology, vol. 22, no. 5, pp. 617622, 2011.

[7] M. S. Meor Yusoff and W. P. Masliana Muslim, "A waste to wealth study on converting aluminium dross schedule waste into $\gamma$ and $\alpha$ alumina," in Recent Advances in Environment, Ecosystems and Development, pp. 17-21, 2009.

[8] B. Lucheva, T. Tsonev, and R. Petkov, "Non-waste aluminum dross recycling," Journal of the University of Chemical Technology and Metallurgy, vol. 40, no. 4, pp. 335-338, 2005.

[9] S. Kumar, A. K. Panda, and R. K. Singh, "Preparation and characterization of acids and alkali treated kaolin clay," Bulletin of Chemical Reaction Engineering \& Catalysis, vol. 8, no. 1, pp. 61-69, 2013.

[10] V. Lakevičs, V. Stepanova, I. Skuja, I. Dušenkova, and A. Ruplis, "Influence of alkali and acidic treatment on sorption properties of latvian illite clays," Key Engineering Materials, vol. 604, pp. 71-74, 2014.

[11] V. R. Choudhary and M. G. Sane, "Effect of preparation conditions of Raney Nickel on its catalytic properties for slurry phase hydrogenation of o-nitrophenol to o-aminophenol," Indian Journal of Chemical Technology, vol. 5, no. 4, pp. 199-208, 1998.

[12] Q. Liu, R. Xin, C. Li, C. Xu, and J. Yang, "Application of red mud as a basic catalyst for biodiesel production," Journal of Environmental Sciences, vol. 25, no. 4, pp. 823-829, 2013. 

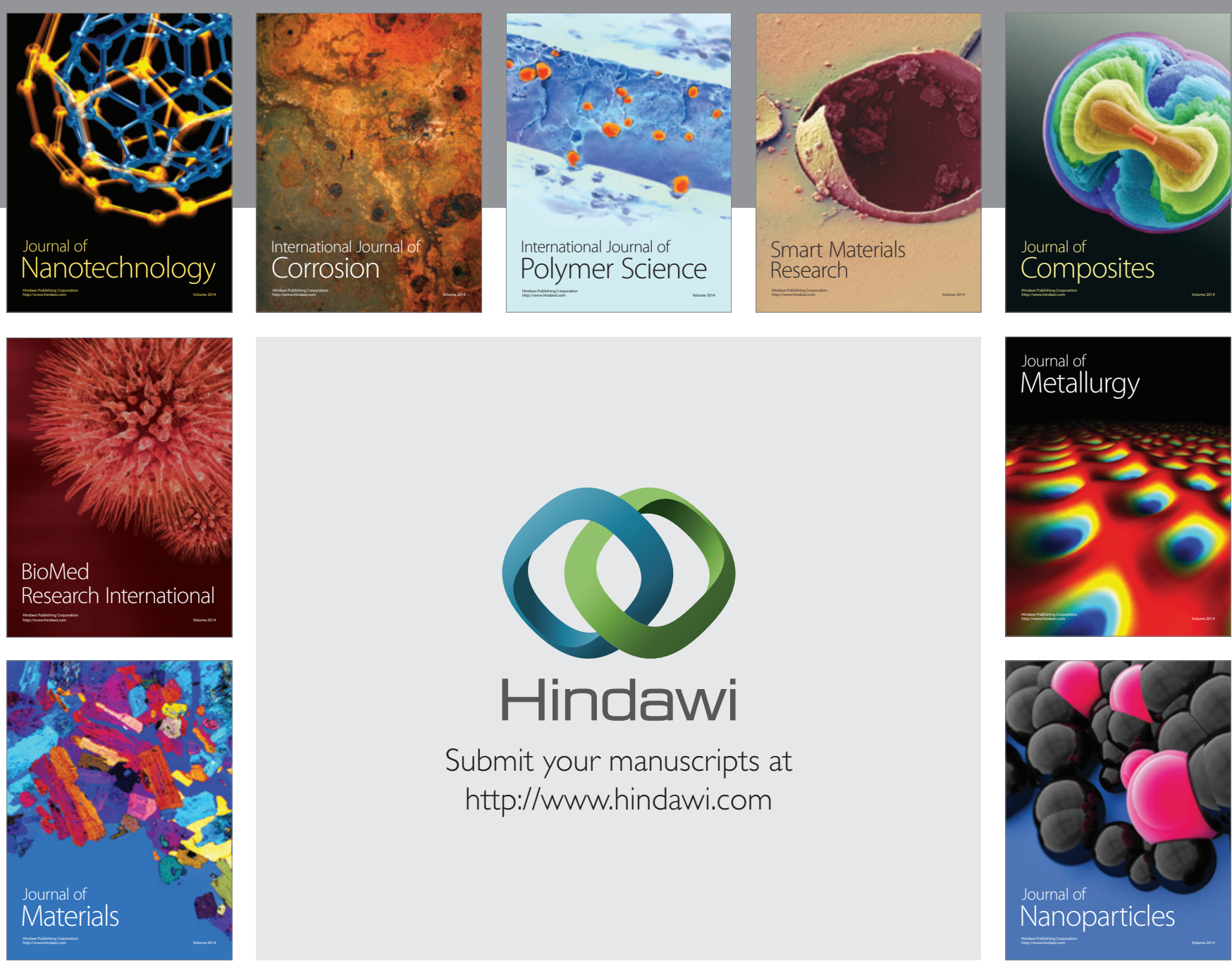

\section{Hindawi}

Submit your manuscripts at

http://www.hindawi.com

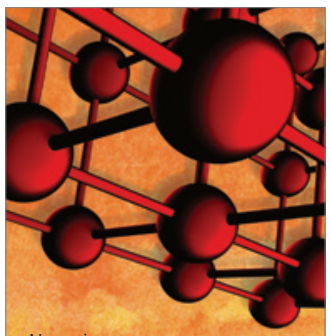

Materials Science and Engineering
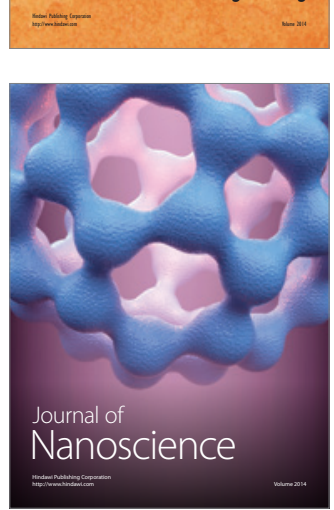
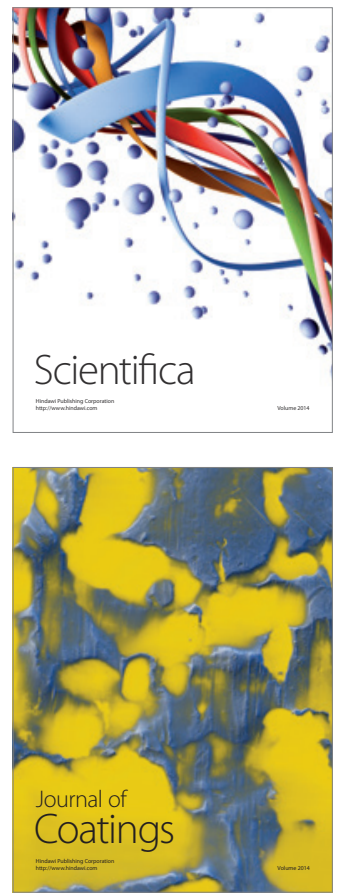
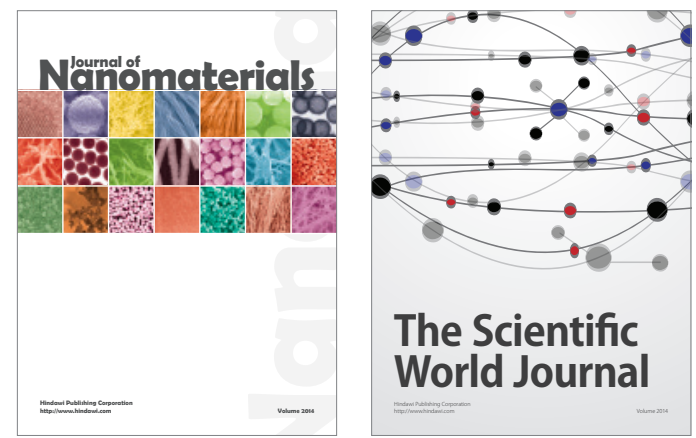

The Scientific World Journal
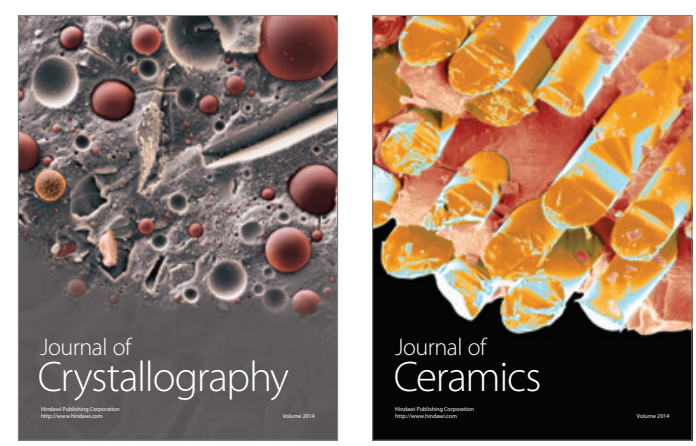
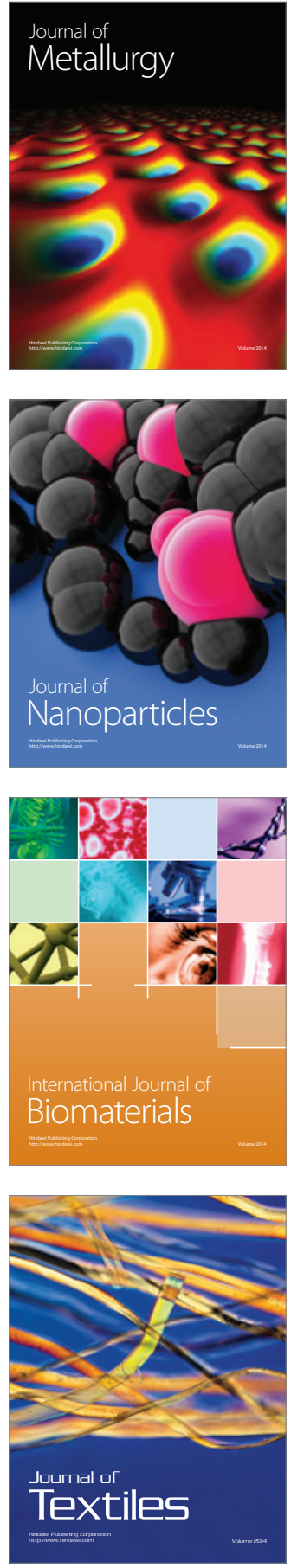